\title{
Imprensa, debates públicos e poder político no Paraguai durante os primeiros anos de ocupação aliada (1869-1870)
}

Bruno Félix Segatto ${ }^{1}$

Resumo: em janeiro de 1869, tropas aliadas tomaram a capital Assunção e deram início, assim, à ocupação político-militar do Paraguai, que durou até 1876. Durante os primeiros anos de ocupação do país, surgiram duas facções políticas que disputaram o poder e a preferência das autoridades aliadas na capital. A partir de outubro de 1869, estas facções passaram a contar com periódicos representantes, dando início, deste modo, à imprensa privada paraguaia. Este artigo objetiva analisar a relação entre imprensa e poder político, além de abordar os principais debates públicos ocorridos durante os anos iniciais de ocupação. Os jornais consultados $L a$ Regeneración, El Paraguay, La Opinión Pública e La Voz del Pueblo estavam atrelados aos grupos políticos locais e atuaram em precárias condições, pois se encontravam sujeitos a pressões e perseguições em um período de ocupação marcado pela desorganização social e política. Apesar das restrições, estes jornais tiveram importante atuação ao inaugurar a prática de debates públicos e livres em um país onde ainda não havia existido liberdade de imprensa e de expressão.

Palavras-chave: imprensa; política; pós-Guerra da Tríplice Aliança.

\section{Press, public debates and political power in Paraguay during the first years of allied occupation (1869-1870)}

\begin{abstract}
In January 1869, allied troops took the capital Asuncion ushering thus the political and military occupation of Paraguay, which lasted until 1876. During the first years of the country's occupation, there were two political factions fighting for power and the preference of the allied authorities in the Capital. From October 1869, these factions have come to have representative's newspapers, ushering the Paraguayan private press. This article aims to analyze the relationship between media and political power and address the main public debates that took place during the early years of occupation. The newspapers consulted, La Regeneración, El Paraguay, La Opinión Pública and La Voz del Pueblo were linked to local political groups and acted in precarious conditions, because they were subject to pressures and persecutions in
\end{abstract}

\footnotetext{
${ }^{1}$ Bolsista de Mestrado junto ao Conselho Nacional de Desenvolvimento Científico e Tecnológico (CNPq). Programa de Pós-Graduação em História - UFRGS. Contato: bf.segatto@ gmail.com.
}

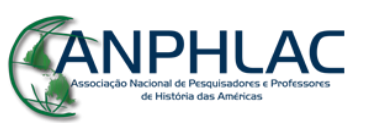


a period of occupation marked by social and political disorganization. Despite the restrictions, these newspapers played an important role in the beginning of the practice of free public debates in a country that never had freedom of press and expression.

Keywords: press; politics; post-War of Triple Allian

Artigo recebido em: 10/01/2016

Artigo aprovado para publicação em: 22/04/2016

\section{Introdução}

Após cinco anos de guerra entre a Tríplice Aliança (Brasil, Argentina e Uruguai) e o Paraguai, este teve sua capital ocupada nos primeiros dias de 1869, enquanto Francisco Solano López seguia resistindo no interior do país. Com a ocupação político-militar de Assunção, acorreu àquela cidade um grande contingente de soldados e autoridades aliadas, integrantes da Legião Paraguaia ${ }^{2}$, comerciantes, correspondentes diplomáticos e de órgãos de imprensa, além de paraguaios que regressavam do exílio na Argentina e uma grande quantidade de sobreviventes oriundos do interior do país.

Nos meses que se seguiram à ocupação aliada, e sob estímulo e influência do representante brasileiro no Paraguai, José Maria da Silva Paranhos, ocorreram reuniões e negociações pela instalação de um governo provisório, que deveria encarregar-se da reorganização político-administrativa das áreas já ocupadas pelas tropas aliadas. Devido a estas negociações, ao longo do primeiro semestre de ocupação se delinearam duas facções políticas interessadas na conquista dos postos públicos do Estado em estruturação: por um lado, constituiu-se um grupo de cidadãos paraguaios que estavam na Argentina que se autoidentificavam enquanto "jovens" e "liberais" e que possuíam como principal referência a família Decoud; por outro lado, agrupou-se uma facção composta por indivíduos que haviam

\footnotetext{
${ }^{2}$ A Legião Paraguaia estava composta por paraguaios contrários ao presidente Francisco Solano Lopez, que se encontravam na Argentina quando do início do conflito. Estava inserida no Exército argentino e tinha o coronel Fernando Iturburu e o tenente-coronel Juan Francisco Decoud como primeiro e segundo oficiais, respectivamente (ESTEVES, 1996, p. 23).
}

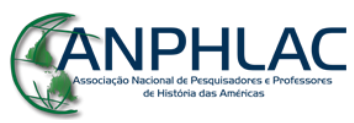

Revista Eletrônica da ANPHLAC, ISSN 1679-1061, №. 20, p. 222-255, Jan/Jun., 2016.

http://revista.anphlac.org.br 
tido relação com os governos López e também por outros que não toleravam a liderança de dita família, estando reunidos em torno de Cándido Bareiro (DORATIOTO, 2002; BREZZO, 1999).

Estas facções divulgaram, através dos seus periódicos representantes, suas percepções a respeito da realidade paraguaia, assim como suas propostas para a reconstrução do país. Representando a facção dos jovens ex-emigrados, estavam os jornais La Regeneración ${ }^{3}, E l$ Paraguay $^{4}$ e La Opinión Pública ${ }^{5}$, enquanto que a facção opositora tinha La Voz del Pueblo ${ }^{6}$ como órgão difusor.

Tendo em consideração que a imprensa no século XIX constituía "el vehículo de proyectos, el instrumento de debate, el propulsor de valores, uno de los principales medios de hacer política, de reproducir y constituir imágenes de la sociedad" (ALONSO, 2003, p. 10), este artigo objetiva analisar a relação entre imprensa e poder político local, abordando os principais debates públicos ocorridos durante os anos iniciais de ocupação do Paraguai. O período compreendido entre a ocupação da capital, em janeiro de 1869, e o juramento da Constituição Nacional, em novembro de 1870, constitui um momento crucial da história paraguaia, pois durante estes meses foram travados inúmeros debates públicos na imprensa que versavam a respeito da sociedade e do Estado em vias de organização, inaugurando, desta forma, a prática de debates livres e de atuação jornalística privada em um país onde ainda não havia vigorado a liberdade de imprensa.

\section{“Sobre cenizas": o Paraguai dos primeiros anos de ocupação aliada}

\footnotetext{
${ }^{3}$ La Regeneración contava inicialmente com Juan José Decoud como redator, passando a seu irmão José Segundo a partir de março de 1870. Sua assinatura custava dois pesos bolivianos e o número solto dos reales fuertes veio a público nos domingos, nas quartas e sextas-feiras entre outubro de 1869 e setembro de 1870 .

${ }^{4}$ El Paraguai era distribuído gratuitamente aos suscritores de La Regeneración; veio a público terças, quintas e sábados durante os meses de maio e junho de 1870. Outro periódico distribuído de forma gratuita aos assinantes de La Regeneración foi o semanário La Luz, que circulou durante o mês de abril de 1870 e não deixou vestígios. ${ }^{5}$ La Opinión Pública tinha Pedro Vera como diretor e José S. Decoud como redator; sua assinatura custava dois pesos bolivianos, e veio a público nos domingos, quartas e sextas-feiras do mês de novembro de 1870 .

${ }^{6}$ Surgido em março de 1870, La Voz del Pueblo tinha o argentino Miguel Gallegos como redator e editor responsável, Florencio Fredes como diretor da parte tipográfica e o também argentino Miguel Macias e o espanhol Victorino Abente y Lago como colaboradores. A suscrición mensal custava dois pesos bolivianos e o número suelto dois reais bolivianos. Veio a público nas terças, quintas e sábados até setembro de 1870 .
}

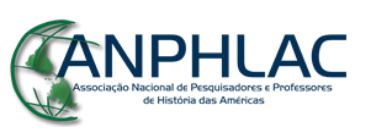

Revista Eletrônica da ANPHLAC, ISSN 1679-1061, №. 20, p. 222-255, Jan/Jun., 2016.

http://revista.anphlac.org.br 
O Paraguai dos meses seguintes à ocupação de Assunção constituía um cenário de desolação. Sua população, que em 1865 era de aproximadamente 500 mil habitantes, em 1870 havia sido reduzida à metade (BREZZO, 2011, p. 200). Tal como afirma Oscar Bogado Rolón (2011, p. 92), no Paraguai do pós-guerra "todo estaba por hacerse".

Conforme Francisco Doratioto, os governantes do Império brasileiro temiam pela independência paraguaia, pois sua situação de debilidade poderia levar à incorporação, voluntária ou não, à Argentina. Desde a ocupação de Assunção até a retirada das tropas em 1876, após a assinatura dos tratados de paz e limites entre Argentina e Paraguai, o Império do Brasil interviu na política interna paraguaia de modo a evitar que políticos considerados "argentinistas" ocupassem cargos públicos importantes no Estado que estava por se reestruturar (DORATIOTO, 2004, p. 210). A pressão e influência brasileira perante os governos paraguaios era tanta que a historiadora argentina Victoria Baratta (2015, p. 30) afirma que entre "1869 y 1874 el Paraguay fue prácticamente un protectorado del Imperio".

Deste modo, a instalação de um governo provisório composto por paraguaios constituía uma medida que o Império endossou acreditando estar garantindo a existência do Paraguai como Estado independente (DORATIOTO, 2014, p. 48). No mês seguinte à tomada de Assunção, chegou à cidade o representante brasileiro José Maria da Silva Paranhos, encarregado de estabelecer o governo provisório. No entanto, esta instalação não ocorreu sem problemas, uma vez que o reduzido círculo de homens que compunham a elite política paraguaia se dividiu enquanto ocorriam as reuniões e negociações para a elaboração de um petitório aos países aliados (DORATIOTO, 1999, p. 28). Algumas querelas vinham desde o período da guerra; outras apareceram em virtude de rancores pessoais, das disputas pelos cargos públicos ou pela proximidade com algum líder político que despontava. Thomas Whigham considera que estas facções "invocaban metas ideológicas, pero actuaban como si los resentimientos personales privados fueran lo más importante. [...]. Carecían de doctrinas y ponían las lealtades (y rencores) personales por encima de otras consideraciones". (WHIGHAM, 2012, p. 403)

Ao longo do primeiro semestre de 1869, delinearam-se duas facções políticas orientadas a ocupar os cargos do governo provisório em vias de constituição: por um lado, encontravamse inúmeros jovens paraguaios auto-identificados como "liberais", que haviam estado no exílio

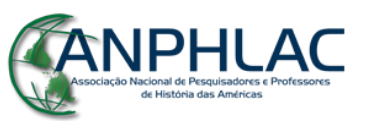


(a maioria na Argentina) e que haviam regressado ao país, como Benigno Ferreira, Salvador Jovellanos, Jaime Sosa Escalada, Juan Silvano Godoy, o Tenente-Coronel da Legião Paraguaia Juan Francisco Decoud e seus filhos Juan José, José Segundo e Adolfo Decoud; de outro lado, formou-se uma facção composta por paraguaios que haviam sido funcionários dos governos López ou tido alguma relação com eles, como Félix Egusquiza e Carlos Saguier, jovens estudantes enviados com bolsa de estudos à Europa, como os irmãos Cayo e Fulgencio Miltos, Juan Jara, e indivíduos que não suportavam a liderança que a família Decoud vinha exercendo, estando reunidos em torno de Cándido Bareiro, ex-representante de López na Europa regressado ao país em fevereiro (ACOSTA TOLEDO, 2013, p. 49).

A divisão entre os paraguaios culminou na criação, em junho de 1869, de dois clubes políticos orientados às eleições para o governo provisório. Defendendo a união entre todos os nacionais, a facção de Cándido Bareiro fundou o Club Unión, enquanto a facção dos jovens liberais organizou o Club del Pueblo (WARREN, 2009, p. 82). Sob estreita supervisão e pressão de José Maria Paranhos, no dia 15 de agosto de 1869 foi instalado o governo provisório paraguaio sob o formato de um triunvirato composto por Carlos Loizaga, José Diaz de Bedoya e Cirilo Rivarola. Juan Francisco Decoud, seus filhos Juan José, José Segundo e Adolfo foram agraciados com cargos na administração do governo, assim como Salvador Jovellanos, Facundo Machaín, Juan Silvano Godoy e Benigno Ferreira, todos membros da facção liberal (WARREN, 2009, p. 98).

Com escassos recursos e em pleno contexto de ocupação político-militar aliada e de desorganização social, o Governo Provisório teve diante de si uma tarefa hercúlea: amparar a população sobrevivente esfomeada e doente, manter a ordem, assentar as bases de um governo permanente, fomentar a agricultura entre outros. A respeito da debilidade do Governo Provisório paraguaio, o periódico montevideano El Siglo publicava o seguinte texto, enviado por um "amigo" correspondente em Assunção:

El Gobierno Provisorio marcha con pies de [ilegível], pues aun si ha ocupado de organizar sus rentas, no hay ni administración de correos ni aduana. Si ha nombrado Municipalidad nada hace a favor de este pueblo; así es que en el Estado que se encuentra, de desaseo, es muy probable que muy pronto se desarrolle alguna epidemia, que con la aglomeración de gente que hay hará grandes estragos. (El Siglo, Montevideo, 18/09/1869).

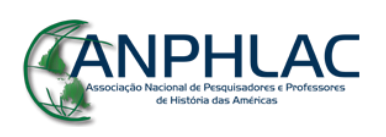


O Governo Provisório foi reconhecido somente pelos países aliados, posto que os demais, como Estados Unidos e França, seguiam reconhecendo Solano López como legítimo representante do governo paraguaio. Esta situação mudou a partir de março de 1870, quando o chefe guarani foi assassinado por tropas brasileiras em Cerro Corá, norte do Paraguai. Sua morte abriu caminho às eleições para uma Assembleia Constituinte, dedicada a elaborar e sancionar a primeira Constituição do país ${ }^{7}$. Também em março de 1870 , os dois clubes políticos assuncenhos tiveram seus nomes alterados: o liberal Club del Pueblo passou a designar-se Gran Club del Pueblo, enquanto que o Club Unión adotou a antiga designação do opositor, passando a chamar-se Club del Pueblo. Os membros deste último, paraguaios ligados a Cándido Bareiro, fundaram o periódico La Voz del Pueblo, passando a atuar na arena periodista assuncenha ao lado de La Regeneración, jornal da facção liberal fundado em outubro de 1869.

As eleições para Constituinte foram celebradas em julho de 1870, resultando em uma expressiva vitória dos candidatos do Gran Club. As primeiras sessões da Assembleia Constituinte foram tensas, devido aos distúrbios causados pela minoria bareirista, disposta a dificultar o andamento dos trabalhos. No dia 31 de agosto, buscando ganhar espaço no cenário político local, os membros do Gran Club conseguiram declarar inoperante o triunvirato e destituir a Cirilo Rivarola (único que restava dos membros do triunvirato). Em seu lugar, assumiu Facundo Machaín como presidente provisório da República. No entanto, no dia seguinte, $1^{\circ}$ de setembro, Cirilo Rivarola, com o apoio das autoridades aliadas em Assunção e do ex-rival Cándido Bareiro, reassumiu o poder, anulou as decisões do dia anterior e destituiu alguns deputados do Gran Club das suas posições na Constituinte e de seus cargos públicos, passando-os aos membros da facção de Bareiro (WARREN, 2009, p. 125).

Aos membros da facção liberal, integrantes do Gran Club del Pueblo, coube, pela primeira vez desde seu retorno ao Paraguai, fazer oposição ao seu antigo aliado Cirilo Rivarola e à tradicional facção rival de Bareiro, então nos cargos públicos e majoritária na Constituinte. A atuação opositora dos liberais ocorreu principalmente por meio do seu órgão representante, o periódico La Regeneración. Porém, esta atuação por meio do jornal durou pouco tempo, dado

\footnotetext{
${ }^{7}$ Em 1844, o Congresso paraguaio aprovou a Ley que establece la Administración política de la República del Paraguay, que representou um ponto de partida para a organização institucional do país, mas "no respondía a los tiempos del moderno constitucionalismo en la medida en que no se especificaban derechos y garantías de los ciudadanos ni se encontraban expresados con claridad los fines del Estado” (ARECES, 2011, p. 173).
}

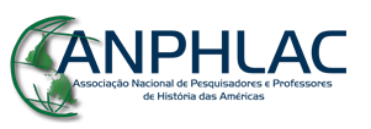

Revista Eletrônica da ANPHLAC, ISSN 1679-1061, №. 20, p. 222-255, Jan/Jun., 2016.

http://revista.anphlac.org.br 
que ao final do mesmo mês de setembro o estabelecimento onde funcionava aquele foi atacado por uma multidão de italianos indignados com uma publicação considerada ofensiva a esta coletividade ${ }^{8}$.

Durante o mês de novembro de 1870 surgiu o periódico La Opinión Pública, órgão que, devido à sua oposição a Rivarola, foi fechado por ordens do governo alguns dias antes do juramento da Constituição Nacional que, entre suas estipulações, sancionava a liberdade de imprensa no país ${ }^{9}$. Como se percebe, imprensa e política estavam diretamente interligadas no Paraguai pós-guerra da Tríplice Aliança, o que torna necessária uma abordagem detalhada a respeito desta instável e conturbada relação.

\section{Imprensa, público e política}

Após ter passado décadas sendo desprezada como fonte histórica por ser considerada registradora de fragmentos realizados sob o influxo de interesses, compromissos e paixões, a imprensa passou a ser revalorizada a partir dos anos 1970 na historiografia brasileira (DE LUCA, 2005, p. 112). Esta mudança ocorreu devido às renovações ocorridas no âmbito da história política e cultural, tal como evidenciada por René Rémond (2003, p. 35), que, rebatendo as críticas feitas àquela historiografia, sustenta que "o político não constitui um setor separado [da sociedade]: é uma modalidade da prática social". Ainda conforme o autor, "o campo do político não tem fronteiras fixas, e as tentativas de fechá-lo dentro de limites traçados para todo o sempre são inúteis” (RÉMOND, 2003, p. 443). Ao relacionar história política com imprensa, resulta necessário ressaltar a contribuição de Maria Helena Capelato para os estudos sobre a imprensa no Brasil:

\footnotetext{
${ }^{8}$ No número do dia 18 de setembro de 1870, o redator de La Regeneración acusou a um italiano de ter assassinado uma mulher em Assunção. No entanto, no número seguinte o mesmo publicou um pequeno texto de retificação em que inocentava o acusado. Aparentemente, esta correção não foi suficiente para conter os ânimos. A destruição da impressora de La Regeneración e as mortes ocorridas no ataque do dia 24 de setembro tiveram repercussão na imprensa platina. Foi noticiada pelos portenhos El Nacional, La Tribuna e La Nación em seus respectivos números do dia 5 de outubro e pelo montevideano El Siglo do dia 7 de outubro de 1870.

${ }^{9} \mathrm{O}$ Artigo 18 do texto constitucional estipulava que todos os habitantes da República gozariam do direito de publicar suas ideias pela imprensa sem censura prévia (ROLÓN, 2011, p. 112).
}

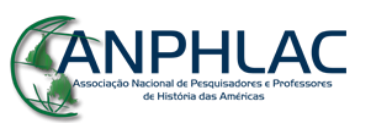

Revista Eletrônica da ANPHLAC, ISSN 1679-1061, №. 20, p. 222-255, Jan/Jun., 2016.

http://revista.anphlac.org.br 


\begin{abstract}
A imprensa constitui um instrumento de manipulação de interesses e intervenção na vida social. Partindo desse pressuposto, o historiador procura estudá-la como agente da história e captar o movimento vivo das ideias e personagens que circulam pelas páginas dos jornais. A categoria abstrata imprensa se desmistifica quando se faz emergir a figura de seus produtores como sujeitos dotados de consciência determinada na prática social. (CAPELATO, 1988, p. 21)
\end{abstract}

Outra importante referência no estudo da imprensa brasileira é a historiadora Marialva Barbosa, que utiliza o modelo proposto por Robert Darnton (1990) para uma história social e cultural da comunicação impressa no Brasil. Conforme a autora, é preciso investigar quem "escreve nesses jornais, como procuram se popularizar - ou seja, que estratégias, apelos e valores evocam -, como funcionam suas empresas e de que forma esses textos chegam ao público" (BARBOSA, 2010, p. 15).

Fábio Wasserman destaca que, a partir das contribuições proporcionadas por esta renovação, surgiram novas abordagens que indagam com mais precisão a incidência que teve a imprensa na configuração da vida pública do século XIX na Argentina, especialmente em Buenos Aires. Para o historiador, estas abordagens apontam para a necessidade de superar as interpretações que tomam a imprensa como um mero suporte de ideias, informações ou representações e de considerá-la como "una práctica productora de sentido y como un actor social y político" (WASSERMAN, 2013, p. 2). Victoria Baratta (2015, p. 3) endossa esta ideia ao caracterizar a imprensa como "actor político destacado de la escena pública, como catalizador principal del debate de ideas de la época”. A imprensa constituía, portanto, peçachave do sistema político argentino, visto que era através dela que o diálogo e a discussão entre personagens e facções políticas ocorriam. Os jornais foram porta-vozes e foros públicos daqueles que competiam pelo poder, e cada vez mais o foram de qualquer indivíduo que quisesse fazer ouvir sua voz e exercer influência em Buenos Aires (SABATO, 2007, p. 185). Endossando a importância da fonte em questão, Fabio Wasserman considera:

La prensa se constituyó en un actor central de esa agitada vida política: instaba temas y candidaturas, representaba a una causa o a un sector, contribuía a la movilización de la población, apoyaba o criticaba al oficialismo de turno. Esta enumeración podría continuar y hacerse más precisa, pero aun así no podría dar cuenta de la importancia adquirida por la prensa, ya que ésta no se debía tan sólo a su carácter de vocera de ideas o intereses, sino más bien a lo que podríamos considerar su función performativa, a su capacidad para darle forma a posiciones, representaciones e identidades que podían ser asumidas $\mathrm{y}$ defendidas por distintos grupos. (WASSERMAN, 2013, p. 5)

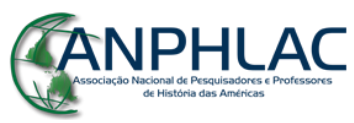

Revista Eletrônica da ANPHLAC, ISSN 1679-1061, №. 20, p. 222-255, Jan/Jun., 2016.

http://revista.anphlac.org.br 
Embora estes autores se refiram principalmente ao contexto oitocentista argentino, suas contribuições são fundamentais para este artigo, dado que a letrada Buenos Aires, com sua intensa produção, circulação e consumo de jornais ${ }^{10}$, com suas inúmeras livrarias, cafés ${ }^{11} \mathrm{e}$ espaços de sociabilidade ${ }^{12}$, havia sido frequentada pelos indivíduos que atuaram na imprensa paraguaia do imediato pós-guerra. A maioria dos integrantes da facção liberal havia vivido anos exilada na capital argentina, enquanto o próprio redator do periódico bareirista $\mathrm{La} \mathrm{Voz} \mathrm{del}$ Pueblo era argentino, assim como o colaborador Miguel Macias. Além disso, Buenos Aires e Assunção se encontravam interconectadas pelos inúmeros barcos a vapor que uniam ambas as capitais, levando consigo passageiros, mercadorias e encomendas, dentre elas exemplares de jornais que espalhavam as notícias de um lugar ao outro ${ }^{13}$. Esta conexão configurava o que Robert Darnton (1990) define como um "circuito de comunicação" que integrava não somente as sedes dos jornais e os portos de ambas as capitais, mas também as ruas, as casas dos assinantes, as residências oficiais dentre outros espaços de sociabilidade.

No número do dia 25 de fevereiro de 1870 de La Regeneración, o anúncio "Retribuciones" citava os periódicos que haviam sido recebidos na sua sede: $\mathrm{La} \mathrm{Paz,El}$ Telégrafo Marítimo, El Ferro-Carril e El Nacional de Montevideo; La República, La Nación, La Tribuna, El Nacional, La Prensa, La Verdad, La Discusión, El Rio de la Plata, Intereses Argentinos e The Standard de Buenos Aires; La Capital, La Reforma e La Patria de Rosario; El Éco de Cordoba e El Progreso de Córdoba; La Juventud de Tucumán; La Voz de Cuyo, de San Juan; El Pueblo de Santa Fé; El Uruguay, La Regeneración, El Gualeguay, El Paraná, El

\footnotetext{
${ }^{10}$ Uma estatística de 1873 assinalava que se distribuíam na cidade quarenta e três diários e periódicos, os quais eram confeccionados nos vinte e seis estabelecimentos impressores da cidade (DE MARCO, 2006, p. 337).

${ }^{11}$ A cidade de Buenos Aires passou por um intenso crescimento econômico e demográfico a partir da década de 1850, a tal ponto que em 1887 contava com cerca de 400 lojas, 100 livrarias e 200 cafés (HORA, 2010, p. 132).

${ }^{12}$ Como reflexo do crescimento econômico e populacional, surgiram novos espaços de sociabilidade na capital e no interior da província: praças, mercados, oficinas, pulperías, cafeterias, livrarias, bibliotecas, sedes de sociedades de ajuda mútua, clubes sociais, culturais e esportivos, lojas maçônicas, associações de imigrantes, círculos culturais, sociedades profissionais, comitês de solidariedade etc. (BERNALDO, 2013, p. 356).

${ }^{13}$ A respeito dos barcos a vapor que faziam a rota Buenos Aires-Assunção, os anúncios da sessão Marítima de $E l$ Nacional, La Tribuna e La Nación citam os seguintes: Venecia, Río de la Plata, Cuyaba, Rio Gualeguay, 34Victoria-34, Goya, Taragui e Guarany. El Nacional do dia 2 de julho de 1870 anunciava a saída do vapor inglês "Rosario" rumo a San Nicolas, Rosario, Paraná, La Paz, Goya, Corrientes, Cerrito, Humaitá e Asunción. As passagens custavam \$50 fuertes en cámera e \$25 fuertes em proa. No La Regeneración de 16 de março de 1870 uma agência publicava um anúncio publicitário informando que os vapores Taragui, Guaraní e Goya chegavam ao porto de Assunção todas as quartas-feiras e partiam todos os sábados.
}

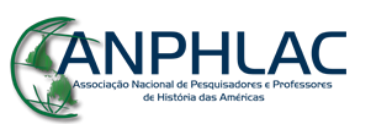

Revista Eletrônica da ANPHLAC, ISSN 1679-1061, №. 20, p. 222-255, Jan/Jun., 2016.

http://revista.anphlac.org.br 
Comercio e El Obrero Nacional de Entre-Rios; La Voz de la Patria e La Esperanza de Corrientes. A grande quantidade de periódicos recebidos, inclusive alguns oriundos de longínquas províncias argentinas como Tucumán e San Juan, evidencia a existência de um "circuito de comunicação" que conectava os publicistas paraguaios com seus colegas argentinos e uruguaios, os quais se liam e frequentemente polemizavam entre si. Barbosa assinala um comportamento semelhante ao estudar a imprensa oitocentista brasileira e destaca:

E são pelos impressos que esses letrados se manifestam publicamente, se aliam, se insultam e se conhecem. Em decorrência, num sistema complexo de autorreferenciação, os jornais citam uns aos outros à exaustão, reproduzindo textos divulgados anteriormente por outro ou comentando aquilo que já fora publicado. Os jornalistas do século XIX escrevem também para eles mesmos. (BARBOSA, 2010, p. 62)

Como se percebe, era maior o número de jornais recebidos da capital argentina, o que se explica pela intensa atividade da imprensa portenha e pela atenção dada por esta aos eventos ocorridos no Paraguai do pós-guerra, o qual frequentemente era associado ao passado recente argentino. O contexto político da Assunção pós-Cerro Corá em algo se assemelhava ao da Buenos Aires pós-Caseros: ambos os episódios - derrotas de governantes que mantinham regimes políticos unanimistas frente a outras lideranças em aliança - deixaram um vazio de poder e uma considerável instabilidade política em 1870 e 1852, respectivamente.

Fabio Wasserman mostra que apesar da maior liberalidade estabelecida com a queda de Rosas em 1852, não existia uma ampla liberdade de imprensa na província portenha, pois uma série de práticas coercitivas e de cooptação da atividade jornalística foi utilizada pelos governos bonaerenses ao longo daquela década. O historiador resgata o relato do chileno Benjamín Vicuña Mackenna, residente na capital argentina durante a década de 1850 para reforçar seu argumento: "Todo lo que no es liberal es mazorquero ${ }^{14}$, y, por consiguiente, prohibido, lo que no puede ser de otro modo en los tiempos de celosa rehabilitación que corren sobre el país" (WASSERMAN, 2009, p. 146). Assim como a reivindicação de Rosas era intolerável na capital portenha, a de Solano López também o era em Assunção, onde a imprensa também atuou em condições instáveis, posto que na prática era ausente a plena libertad de imprenta.

\footnotetext{
${ }^{14}$ A Mazorca era o braço armado da Sociedad Popular Restauradora, um clube político composto por apoiadores fervorosos de Juan Manuel de Rosas (DI MEGLIO, 2007).
}

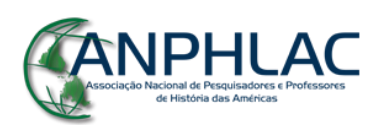

Revista Eletrônica da ANPHLAC, ISSN 1679-1061, №. 20, p. 222-255, Jan/Jun., 2016.

http://revista.anphlac.org.br 
Conforme Alfredo Seiferheld (2016), o periodismo no Paraguai nasceu relacionado com sua independência política. Excetuando a publicação de Repertorio Nacional, a partir de 1841, por seu caráter de "diário oficial", o autor ressalta que El Paraguayo Independiente, surgido em 1845, foi o primeiro periódico publicado no país. Sob a direção do presidente Carlos Antonio Lopez, o jornal estava orientado a defender o território nacional e a reclamar o reconhecimento da independência do país por parte de Juan Manuel de Rosas. Uma vez reconhecido como Estado independente pela Confederação Argentina em 1852, a publicação oficial deixou de circular. Em referência aos dois jornais citados, Juan Crichigno (2010, p. 20) afirma que "los periodicos de [Carlos Antonio] Lopez carecían de opinión, debate y polémica o discusión. Se limitaban a informar y a fijar el ordenamiento de la vida ciudadana".

Durante a década de 1850, surgiram outras publicações que também tinham caráter oficial: El Semanario de Avisos y Conocimientos Útiles, Eco del Paraguay, La Época e La Aurora (CRICHIGNO, 2010; SEIFERHELD, 2016). Durante a década de 1860, apareceram os periodicos de trinchera que marcariam a história da imprensa e cultura paraguaias por sua singularidade. El Centinela, Cabichuí, Cacique Lambaré e La Estrella constituíam o que Ticio Escobar designa "imprensa combativa", uma vez que foram usados como instrumentos de moralização, propaganda e doutrinação (ESCOBAR, 1995, p. 123) ${ }^{15}$.

A imprensa surgida durante os primeiros anos de ocupação político-militar de Assunção estava diretamente vinculada à política local: La Regeneración, El Paraguay e La Opinión Pública eram os órgãos difusores da facção liberal, enquanto La Voz del Pueblo o era do grupo bareirista. Eram os primeiros periódicos privados surgidos no país, tendo em vista que até então somente haviam circulado jornais oficiais que eram redigidos e impressos em estabelecimentos dos governos López, os quais não permitiam a atuação de imprensa de oposição no país (CRICHGNO, 2010, p. 29).

Se na Argentina pós-Caseros a imprensa se converteu em uma peça chave do sistema político, uma vez que era considerada a expressão e origem da opinião pública e um elemento de civilização (SABATO, 2004, p. 70), no Paraguai pós-Cerro Corá não era diferente. A respeito do rol da imprensa, José D. Gonzalez y Abalos, um dos colaboradores de La

\footnotetext{
${ }^{15}$ A respeito dos periodicos de trinchera paraguaios, ver TORAL (2001), CAMPOS e SEGOVIA (2006), JOHANSSON (2012), ESCOBAR (2016), AMIGO (2016).
}

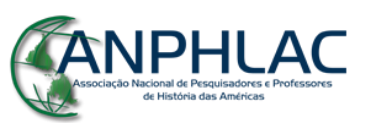

Revista Eletrônica da ANPHLAC, ISSN 1679-1061, №. 20, p. 222-255, Jan/Jun., 2016.

http://revista.anphlac.org.br 
Regeneración, teve seu artigo "La escuela, la prensa y el estado" publicado no número do dia 21 de outubro de 1869:

La prensa es libre, ilustra, aconseja y reprende, a los Gobiernos y a los pueblos. La prensa es el tribunal de la opinión pública.

Juzga premia y castiga a todas las clases de la sociedad.

La prensa es la palanca del progreso.

A su influencia deben los pueblos la prosperidad del comercio de las artes y de las ciencias.

La prensa es universal; Menos rápida, pero más elocuente que el telégrafo, pone en comunicación a la naciones.

La prensa es poderosa.

Une o divide las sociedades, calma ó irrita las pasiones, edifica o destruye, según el espíritu que le anima.

La prensa no debe ser licenciosa ni servil.

La prensa debe ser libre, circunspecta y moral.

Los Gobiernos tiránicos ahogan la voz de la prensa.

Los Gobiernos liberales la protejen y la escuchan.

Los Gobiernos débiles le temen y los fuertes la provocan. (La Regeneración, Assunção, 21/10/1869)

No primeiro número de La Opinión Pública ${ }^{16}$, assim se referia seu redator ao significado da imprensa:

La aparición de un periódico en las actuales circunstancias, q' se haga órgano de la opinión pública y de los intereses generales del país, importa una necesidad latente manifestada por todos los hombres de buen sentido. La prensa, esa preciosa institución creada por el genio para difundir los conocimientos más útiles del saber humano y para restrinjir los avances del poder, reducida como se encuentra al monopolio y servilismo d' unos cuantos, no puede llenar en manera alguna su vasta y elevada misión. (La Opinión Pública, Assunção, 06/11/1870)

Apesar de estes jornais serem independentes, isso não significava plena liberdade e autonomia, pois até mesmo a fundação de um periódico na capital paraguaia dependia da aprovação das autoridades aliadas e do Governo Provisório (WARREN, 2009, p. 243). Além disso, por um lado, seus redatores e proprietários costumavam depender de subsídios do dito

\footnotetext{
${ }^{16}$ A respeito do termo "opinião pública", Jurgen Habermas sustenta que a esfera pública é resultado de um processo gradual que ocorre em simultaneidade à consolidação dos Estados nacionais de base territorial na Europa e que está vinculado à consolidação do capitalismo. Este processo é marcado pelo afastamento entre a sociedade e o Estado, na medida em que aquela se contrapõe à autoridade deste. A crítica se apresenta, então, como "opinião pública" e não é mais exercida em caráter privado, sendo a imprensa uma instância privilegiada de interpelação do poder público (HABERMAS, 2014).
}

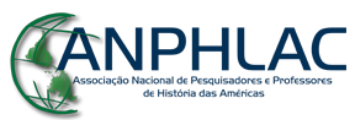

Revista Eletrônica da ANPHLAC, ISSN 1679-1061, №. 20, p. 222-255, Jan/Jun., 2016.

http://revista.anphlac.org.br 
governo em troca da publicação de documentos oficiais, o que exigia, no mínimo, boa relação com o mesmo, e, por outro, estavam sujeitos às perseguições daquele e aos ataques perpetrados por membros dos soldados de ocupação e de outros grupos da capital.

Em julho de 1870, os responsáveis pelo periódico argentinista La Voz del Pueblo intensificaram suas críticas à influência brasileira no Paraguai. Nos seguintes excertos de seus artigos verifica-se o nível de instabilidade em que atuavam os redatores, editores e colaboradores daquele jornal:

\begin{abstract}
Mucho se ha dicho en el mundo sobre la libertad de imprenta, y mucho papel se ha borroneado también, pretendiendo negarle ese derecho al hombre. Nada ha bastado empero, pues aun hoy hombres que como los que escriben en el "Brasil y Portugal"17, bastante conocidos nuestros ${ }^{18}$ por cierto, se empeñan en seguir haciendo doctrina retrógrada, después que impotentes y derrotados, no han podido aprisionar y llenar de cadenas, como hubiesen deseado, al Redactor de "La Voz del Pueblo", porque se permitió, sin el consentimiento del Caray ${ }^{19}$ referir los abusos de confianza de los hombres que por ahí andan figurando como serios y ajenos a las luchas de esta pobre tierra. (La Voz del Pueblo, Assunção, 14/07/1870)
\end{abstract}

Alguns dias depois, após publicar um duro artigo criticando a atuação da diplomacia brasileira no Paraguai, a oficina do periódico La Voz del Pueblo quase foi destruída durante a noite por soldados brasileiros, os quais, aparentemente, teriam se equivocado de estabelecimento, havendo destruído e roubado uma residência vizinha em que residia um grupo de mulheres:

La tormenta que se descargó al fin en la noche del 15 del corriente, no la hemos provocado nosotros que no hemos hecho más que decir verdades; esa tormenta ha sido el resultado lójico de la impotencia de los que no teniendo razones que oponer a las nuestras, han querido matar la voz de la verdad, echando una imprenta a la calle, como si quince días después no habíamos de tener otra imprenta planteada, y otra vez la facilidad de denunciar los déspotas para que el mundo entero los maldijese cien veces más. [...] Porque hemos dicho que soldados brasileros ${ }^{20}$ atacan una casa con la idea de echar una imprenta a la calle; [...] Toda nuestra oposición es á la política del Consejero Paranhos, como seria a la del Ministro Argentino si lo viésemos influyendo en lo más mínimo en los asuntos locales del Gobierno Provisorio del Paraguay. ( $L a$ Voz del Pueblo, Assunção, 19/07/1870)

\footnotetext{
${ }^{17}$ Periódico escrito em português, que não deixou resquícios.

${ }^{18}$ Grifos do original.

${ }^{19}$ Grifos do original. Em guarani Karai significa "senhor".

${ }^{20}$ Grifos do original.
}

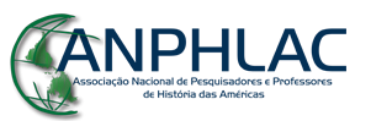

Revista Eletrônica da ANPHLAC, ISSN 1679-1061, №. 20, p. 222-255, Jan/Jun., 2016.

http://revista.anphlac.org.br 
As disputas entre liberais e bareiristas e seus respectivos órgãos difusores, assim como a interferência brasileira nos assuntos internos do Paraguai, eram constantes pontos de debate público também na imprensa de Buenos Aires. Não é de estranhar que o seguinte "Boletín" de La Voz del Pueblo, bastante crítico em relação ao Brasil, tenha sido reproduzido pelo periódico portenho El Nacional, o qual não ocultava suas antipatias em relação ao Império do Brasil e sua oposição à Tríplice Aliança formada em 1865:

Paraguay. Boletín de la "Voz del Pueblo". Asunción, Junio 30 de 1870.

[...] Ahora ya no tienen que dudar los hijos del pueblo. El Gobierno Provisorio, es Gobierno Brasilero, y las tres mil bayonetas que tienen en la Asunción, cuatro ó cinco mil que se hallan en Humaita, y toda la armada en estación en el puerto, han de dirijir sus tiros al corazón de los hijos de la nación, en el primer momento que quieran manifestar la soberanía que les han prometido. [...] El pueblo paraguayo ha sido pues conquistado, y de hoy en adelante la Redacción de "La Voz del Pueblo", defiende a los derechos del Pueblo, no ya usurpado por un Gobierno dictatorial, sino por un poder estraño que viene imprudentemente a comprometer una situación arrojando chispas sobre la Santa-Barbara. (El Nacional, Buenos Aires, 07/07/1870)

Em setembro de 1870, tanto La Regeneración, em seu primeiro mês de atuação opositora ao Governo Provisório, quanto o então governista La Voz del Pueblo, deixaram de circular devido à destruição de suas impressoras em violentos ataques perpetrados por desconhecidos (WHIGHAM, 2012, p. 418). E, em novembro de 1870, devido às críticas a Cirilo Rivarola, então presidente provisório do país, o periódico La Opinión Pública foi fechado por ordens do governo, alguns dias antes do juramento da Constituição Nacional que estipularia a liberdade de imprensa no país.

Além da vigilância, das perseguições e dos atos de violência aos quais se encontravam expostos, os proprietários, redatores e colaboradores também lutavam diariamente pela subsistência econômica dos seus jornais. Para os que tinham boa relação com o Governo Provisório os subsídios oficiais garantiam bons ingressos, contudo não podiam se restringir a isso. Os redatores e/ou proprietários também buscavam incrementar suas rendas por meio das assinaturas mensais (suscrición), anúncios publicitários, avisos, alugueis da impressora e impressões em geral.

Cabe enfatizar que neste contexto, mesmo na capital argentina, a atuação de redator ainda se encontrava em vias de profissionalização, sendo raros os casos de redatores que viviam somente desta função. Juan José e José Segundo Decoud, redatores de La Regeneración, El

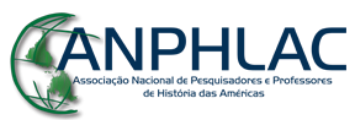

Revista Eletrônica da ANPHLAC, ISSN 1679-1061, №. 20, p. 222-255, Jan/Jun., 2016.

http://revista.anphlac.org.br 
Paraguay e La Opinión Pública, assim como os colaboradores destes órgãos, também ocupavam cargos no Governo Provisório até setembro de 1870 e exerciam o mandato de deputados convencionais. Do mesmo modo, o redator de La Voz del Pueblo, o argentino Miguel Gallegos, era cirurgião do Hospital Argentino em Assunção; os colaboradores também passaram a exercer cargos no governo provisório a partir de setembro de 1870, e foram também deputados convencionais. Neste sentido, resulta pertinente a proposição de Wasserman no sentido de considerar os redatores de jornais em aproximação à figura do "publicista", aquele que "por su formación o profesión tenían la capacidad de hacer uso de la palabra escrita y la utilizaban para dar a conocer ideas o sentar posiciones sobre temas que pudieran ser de interés público" (WASSERMAN, 2013, p. 9).

Além dos proprietários, redatores e colaboradores, os quais tinham seus nomes impressos e se tornavam conhecidos na cidade, também atuavam inúmeros outros indivíduos que não ganhavam a mesma notoriedade: tipógrafos, editores, tinteiros, compositores caixistas, distribuidores e serventes em geral. Importante ressaltar que não eram somente homens, dado que no contexto do Paraguai pós-guerra a população masculina adulta era escassa, sendo as mulheres ${ }^{21}$ que desempenhavam algumas destas funções, como se percebe no aviso publicado por La Regeneración do dia 31 de outubro de 1869: "En esta Imprenta se necesita una mujer para doblar periódicos y tirar el pliego de la prensa. [...] También se ofrece enseñar a la que desee aprender el arte del tipógrafo, pudiendo ganar sueldo al mes subsiguiente de su entrada”. E, em 13 de março de 1870, outro anúncio dizia: "En esta Imprenta se necesita un hombre que quiera hacerse cargo de la repartición del periódico; se le hará las mejores propuestas y solo se le exigirá una completa exactitud al repartir a los suscritores”.

O jornal portenho La Nación, ao noticiar a destruição da oficina de La Regeneración, publicou uma correspondência oficial destinada ao Chefe do Departamento da Capital, Rufino Taboada, na qual nomeava a três empregados do estabelecimento, dois homens (um deles brasileiro) e uma mulher:

Tan triste perspectiva pronto me dejó convencido de que en aquella casa debió tener lugar un hecho bárbaro y violento; pasé hasta el patio y encontré tendido sobre un

\footnotetext{
${ }^{21}$ A respeito da relação entre imprensa e mulheres paraguaias no pós-guerra, ver ORTOLAN (2010) e SILVA (1998).
}

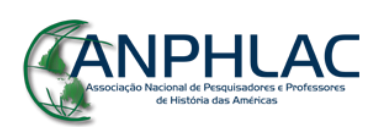

Revista Eletrônica da ANPHLAC, ISSN 1679-1061, №. 20, p. 222-255, Jan/Jun., 2016.

http://revista.anphlac.org.br 
catre un cadáver que dijeron ser de Fernando Antonio de Araujo, quien había sido operario de aquella imprenta y victima de la bárbara agresión de los italianos [...]; pregunté si había algún herido y no tardó en presentarse D. Javier Diniz, operario también de la misma imprenta, herido de un balazo en el hombro; [...] Al concluir de tomar estas declaraciones, se presentó Maria Gertrudis Rivas, sirviente de la misma casa [...]. (La Nación, Buenos Aires, 06/10/1870).

Outra característica desta nascente imprensa privada assuncenha era o curto período de circulação dos seus jornais, algo comum entre os periódicos platinos durante a década de 1870 . Embora existissem periódicos com larga trajetória, como os portenhos El Nacional (1852), La Tribuna (1853) e La Nación (1862) e o montevideano El Siglo (1863), a maioria dos periódicos platinos não circulava por muitos anos, havendo inclusive aqueles que existiam em função de alguma causa ou candidatura política, perdendo sua razão de existir uma vez alcançado tal objetivo ou terminada uma campanha eleitoral. Dificuldades financeiras, conflitos entre editores e/ou redatores, perseguições perpetradas pelos governos locais e destruição das máquinas impressoras constituem outros fatores que explicam esta curta existência.

Ao contrário do que ocorria em Buenos Aires, onde havia um grande público leitor dos inúmeros jornais que se encontravam em circulação e que inclusive chegavam às localidades do interior da província ${ }^{22}$, em Assunção este público se encontrava reduzido principalmente ao âmbito urbano, sendo, provavelmente, assim distribuído: os assinantes (suscritores), o reduzido círculo de homens que compunham a "elite política" paraguaia, as vigilantes autoridades aliadas que se encontravam no país, os correspondentes diplomáticos e de órgãos de imprensa, os comerciantes estrangeiros que se instalaram naquela cidade, assim como os membros dos exércitos de ocupação.

Harris Warren (2009, p. 50) afirma que a população de Assunção em 1869 seria de 17 mil habitantes e que "supuestamente el tiraje de las dos publicaciones juntas [La Regeneración e La Luz] llegaba a 800 ejemplares, con 4.000 lectores", embora não apresente referências quanto a esta última informação (WARREN, 2009, p. 243). Se verdadeiros, estes números ficam pequenos se comparados aos trinta mil leitores que La Tribuna, jornal mais vendido na

\footnotetext{
${ }^{22}$ Hilda Sabato afirma que em $186950 \%$ dos homens e $43 \%$ das mulheres da cidade de Buenos Aires sabiam ler e escrever, contabilizando um total de $63 \%$ da população adulta da capital (2007, p. 186). William Acree (2013), por sua vez, destaca que a região do Rio da Prata se destaca pela existência de uma cultura impresa rioplatense e de um considerável público consumidor de literatura popular que, segundo o autor, tem suas origens nas guerras de independência e que colocam a região dentre as com maior porcentagem de alfabetizados na América Latina.
}

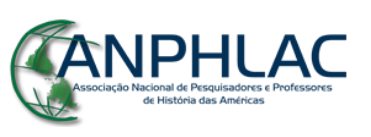


Argentina naqueles anos, vangloriava-se em anunciar no seu número dos dias 10 e 11 de julho de 1870.

Adelina Pusineri, por sua vez, assinala que as discussões ocorridas na imprensa assuncenha tiveram reduzido impacto entre a população paraguaia em geral, ocupada em buscar a sobrevivência naquele contexto de anarquia e miséria (PUSINERI, 2005). Thomas Whigham endossa esta afirmação ao considerar que "Para las masas que todavia estaban peleando por un pedazo de chipa o un trozo de carne seca, los eslóganes no significaban nada en absoluto..." (WHIGHAM, 2012, p. 419).

Embora seu público leitor estivesse concentrado na capital paraguaia, estes jornais circulavam também pelo exterior através dos barcos a vapor que conectavam a cidade às capitais Buenos Aires e Montevideo, passando antes por cidades portuárias como Corrientes, Paraná e Rosario. Nestas localidades, os eventos ocorridos em Assunção eram noticiados pelos jornais locais, os quais manifestavam seu apoio ou rechaço às facções políticas paraguaias em disputa, como se destaca em um texto de El Paraguay:

\begin{abstract}
Transcribimos á continuación un artículo del "Comercio" periódico que se publica en la ciudad del Paraná, y por el que verán nuestros lectores que nuestra propaganda y nuestros esfuerzos reciben la merecida justicia en el esterior. En vano nuestros detractores y los que quieren negar todo mérito y virtud á la juventud paraguaya, como los colaboradores de "La Voz del Pueblo", pretenderán denigrarnos con personalidades y miserias. (El Paraguay, Assunção, 28/05/1870)
\end{abstract}

E, apesar de seu público leitor estar constituído principalmente por um círculo de homens letrados, resulta digno de nota ressaltar o importante peso que tinha a oralidade na transmissão de informações em sociedades marcadas pelo analfabetismo ou, tal como a paraguaia, pela ausência de uma tradição de livre circulação de jornais e de debates públicos. Portanto, o fato de que os jornais paraguaios tivessem um público consumidor letrado e urbano não implica que suas informações, projetos e ideias não tenham circulado também por ambientes rurais ou onde imperava o analfabetismo, uma vez que as informações corriam também através das leituras públicas, dos rumores, dos boatos, dos papeis e folhetos distribuídos pelas ruas, grudados nas portas e paredes de edifícios públicos, igrejas ou casas ou jogados pelas ruas durante a madrugada (BARBOSA, 2010; MOREL, 2012; ACREE, 2013),

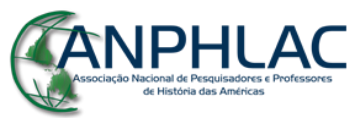

Revista Eletrônica da ANPHLAC, ISSN 1679-1061, №. 20, p. 222-255, Jan/Jun., 2016.

http://revista.anphlac.org.br 
como se percebe no seguinte aviso: “Ayer se repartió por las calles un cartelito anunciando la próxima aparición del nuevo periódico, que se llamará "La Voz del Pueblo"” (La Regeneración, Assunção, 13/03/1870).

Partindo do pressuposto de que oralidade e escrita não são excludentes, conforme sustenta Erick Havelock (1995), Marialva Barbosa (2010, p. 51) evidencia que as marcas de oralidade constituem características marcantes da imprensa brasileira oitocentista e considera que "os impressos se esparramam pela sociedade pelas práticas da oralidade". Do mesmo modo, ocorria na imprensa paraguaia, onde os rumores e os boatos que corriam de boca em boca eram passados para o papel através do trabalho de redatores, tipógrafos e compositores caixistas, como se percebe nos seguintes excertos escritos pelos redatores de La Regeneración, expectantes quanto à notícia da aparição de um novo periódico em Assunção:

Un nuevo periódico. Corre con generalidad en el pueblo que va á establecerse otro periódico en esta ciudad. Al efecto se ha levantado una suscripción que según se nos dice $e^{23}$ ha llegado a ser suficiente para costear una nueva Imprenta. El pensamiento es exelente. Hacemos votos por su pronta realización. (La Regeneración, Assunção, $22 / 12 / 1869)$

Em outro momento, José Segundo Decoud noticiava, baseado em rumores, que haviam sido acordados os tratados preliminares entre os Ministros Plenipotenciários aliados com os seguintes termos:

\footnotetext{
Diplomacia. Parece que han sido arreglados definitivamente los tratados preliminares entre los Ministros Plenipotenciarios. Corre la $v^{2} z^{24}$ que los arreglos definitivos, quedan suspendidos hasta la elección del Gobierno Constitucional, único competente y autorizado para darles una solución conveniente. Por lo demás, se dice que el Sr. Consejero Paranhos muy pronto se retirará a Rio de Janeiro, adonde es llamado con motivo de la apertura de las Camaras Legislativas. (La Regeneración, Assunção, 27/04/1870)
}

Apesar das condições instáveis de atuação, das dificuldades financeiras, da existência efêmera e atrelada aos grupos políticos, das perseguições, pressões e intimidações governamentais e das tentativas de destruição das máquinas impressoras, os jornais que deram

\footnotetext{
${ }^{23}$ Grifos do autor.

${ }^{24}$ Grifos do autor.
}

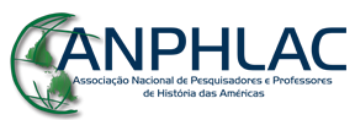


origem à imprensa privada no Paraguai assumiram um importante rol político e social ao inaugurar a prática de debates públicos e livres no país, como se verá adiante.

\section{Debates públicos e livres: uma novidade}

Embora os reais "donos" da situação política naquela Assunção pós-Cerro Corá fossem as vigilantes autoridades aliadas, sobretudo o "Virrey" 25 do Paraguai José Maria Paranhos, havia certa margem de manobra para as facções políticas paraguaias, as quais aprenderam a tirar proveito das discordâncias entre brasileiros e argentinos: "Ninguna se complacía de tener a Brasil o Argentina como procuradores, pero nadie veía otra alternativa que ofrecerse al mejor postor” (WHIGHAM, 2012, p. 406). A partir da ocupação da capital, o grupo liberal e a facção de Bareiro passaram a disputar pelo poder e pelos cargos do Estado por reestruturar, e nesta disputa, travada principalmente através dos jornais locais, inúmeros foram os temas de debate que agitaram o cenário político local, dando início à prática de debates públicos e livres via imprensa privada.

Inúmeras foram as questões que dividiram opiniões entre a elite política paraguaia, mas alguns temas tiveram mais repercussão que outros, sobretudo aqueles relacionados ao futuro e ao passado do país. Embora partissem de um solo comum liberal, republicano e anti-lopista, liberais e bareiristas se diferenciavam quanto a algumas medidas a serem implementadas na reconstrução paraguaia e na interpretação sobre os governos paraguaios anteriores a 1870.

Duas principais propostas defendidas pelo Gran Club, a facção liberal, eram a "regeneração" do povo paraguaio e a instituição de uma Constituição de caráter liberal no país. $\mathrm{Na}$ visão dos liberais, o povo guarani havia sido vítima de séculos do despotismo colonial, do jesuitismo e, mesmo após a emancipação da Espanha, de décadas das tiranias de José Gaspar Rodrigues de Francia (1811-1840), de Carlos Antonio (1840-1862) e de Francisco Solano López (1862-1870). No primeiro número de La Regeneración, Adolfo Decoud assim se expressava quanto ao passado paraguaio:

\footnotetext{
${ }^{25}$ O termo "Virrey", que faz referência aos Vice-Reis da Coroa espanhola na América hispânica, foi aplicado ao conselheiro Paranhos por argentinos, uruguaios e paraguaios, devido à intervenção do mesmo em assuntos internos do Paraguai (WHIGHAM, 2012, p. 419).
}

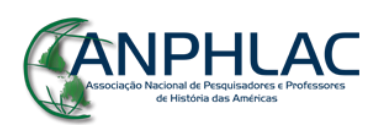


Ya se ha dicho que Nuestro Pasado es el jesuitismo, el fanatismo, los dogmas de odio y el "guaraní", espantosa creación de la ignorancia, del retroceso, digno de ser aplaudido por los apóstatas que se servían de él como enemigos de todo progreso y civilización. El jesuitismo dejó pues en el Paraguay una huella tenebrosa, y su obra ha sido la destrucción, el hecatombe que se ha presenciado y que llenará de luto las páginas de la historia... Tal es Nuestro Pasado ciudadanos! (La Regeneración, Assunção, 01/10/1869).

Os séculos de tirania e despotismo teriam inculcado no povo paraguaio a ignorância, o servilismo, a obediência cega, a submissão e a indiferença, sendo necessária a sua "regeneração" por meio da instrução pública e da imigração europeia. Em março de 1870, El Paraguay assim se posicionava em relação à imigração: "Esto es lo que queremos; que vengan cien mil inmigrantes. - La inmigración para el Paraguay es sinónimo de libertad, felicidad, grandeza, \&. - La inmigración es el arma más poderosa tal vez contra los tiranos” (El Paraguay, Assunção, 21/05/1870). No mesmo dia, o pequeno texto "A los estrangeros" dizia: "Puede estar segura la población estrangera de que "El Paraguay” será uno de los [ilegível] sostenedores de la inmigración, de la industria y del progreso en este país". Introduzir milhares de imigrantes europeus em território paraguaio seria uma medida fundamental para repovoar os campos e as cidades e reativar o comércio e a agricultura, mas não poderiam ser quaisquer imigrantes: a preferência era pelos oriundos do norte da Europa ${ }^{26}$.

Em longo prazo, por outro lado, os liberais defendiam o incentivo à instrução pública, a qual deveria ilustrar o povo e ter os países nórdicos como paradigmas, como ressaltava Juan José Decoud:

La educación jesuítica produjo 60 años de despotismo y a tres monstruos que no tienen igual en la historia. La educación racionalista producirá la libertad, la civilización y el progreso, como ya lo ha producido en los Estados Unidos y en Inglaterra. Por una parte vida, animación y alegría, por otra muerte, enervación y terror. Es decir, Roma y España con sus frailes, frente a Londres y New York con sus locomotores y sus vapores. Nuestra senda ya la hemos trazado. ¡Guerra a la corrupción sostenida por el jesuitismo. (La Regeneración, Assunção, 10/11/1869)

\footnotetext{
${ }^{26}$ A política imigratória no Paraguai teve seu início ainda durante o governo de Carlos Antonio Lopez com a criação da colônia francesa Nueva Bordeos, no Chaco. No entanto, tal iniciativa fracassou devido a divergências entre os colonos e o governo paraguaio (LOPEZ MOREIRA, 2013, p. 193).
}

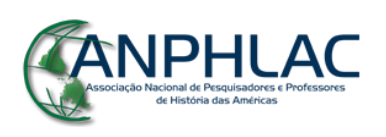

Revista Eletrônica da ANPHLAC, ISSN 1679-1061, №. 20, p. 222-255, Jan/Jun., 2016.

http://revista.anphlac.org.br 
Outra proposta dos liberais era a aprovação de uma Constituição nacional de caráter liberal que garantisse as liberdades econômicas, políticas e individuais, a divisão do Estado em três poderes, o Estado laico, o matrimônio civil, entre outros. Os membros do Gran Club deram especial ênfase a esta proposta, uma vez que até então o Paraguai não contava com uma constituição e havia tido governos autocráticos que não respeitavam as liberdades políticas, individuais e econômicas: não havia liberdade de imprensa nem de expressão, não era tolerada atuação política opositora e grande parte das terras era propriedade do Estado paraguaio. Portanto, os liberais defendiam a criação de mecanismos legais que impedissem o ressurgimento de um regime rosista ou lopista no país:

\footnotetext{
Queremos igualmente un respecto profundo para la persona, para la conciencia y para la propiedad del Ciudadano; queremos que la condición del poderoso y del [ilegível] sea igual [ilegível] las leyes.

Respecto al orden judicial, queremos la reforma en la ejecución, no imitemos al tirano Lopez, consultemos las dos escuelas "histórica y filosófica", queremos la unidad de Códigos, una justicia cierta, ilustrada y pronta, administrada por majistrados decorosamente dotados y responsables de sus actos y queremos abolición de las jurisdicciones privilegiadas en los negocios comunes, y el conveniente arreglo de los tribunales civiles y criminales.

En el orden económico y administrativo, deseamos protección a las empresas útiles, destino anual de Capitales [ilegível] a obras públicas, y apoyo y fomento eficaz para la industria agrícola, fabril y mercantil; conviene la fascinación de estadistas generales, el establecimiento de tribunales administrativos, la supremacía del poder civil, el arreglo de Correo para [ilegível] los pueblos de Campaña, la elección de funcionarios entendidos y probos. (La Regeneración, Assunção, 14/10/1869)
}

Quando redator de La Regeneración, Juan José Decoud publicou um "Proyecto de Constitución para el Paraguay", o qual colocou a consideração do público leitor como proposta de lei fundamental para o país, instalando a discussão pública a respeito de uma assembleia constituinte (ROLÓN, 2011). Vindo a público, em textos segmentados, entre outubro e novembro de 1869, este projeto estava composto por um preâmbulo, 15 capítulos, 118 artigos e um texto de conclusão. Estava claramente inspirado nas constituições argentina e norteamericana, sendo seu preâmbulo muito semelhante aos destas. No texto de conclusão do projeto, Juan José Decoud assim se refere a tal iniciativa:

Nuestra opinión siempre ha sido que debemos introducir todo lo mejor y más perfecto en nuestro país; que debemos arrancar de raíces todos los restos del pasado

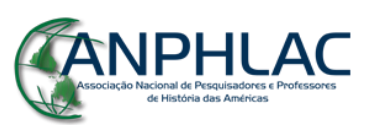


despotismo ${ }^{27}$ y levantando los altares de la Patria sobre una Constitución sabia, preparar días felices de paz y prosperidad para las generaciones futuras. [...] La Constitución marca el grado de civilización de un pueblo, es el barómetro de su progreso y demarca más o menos en el horizonte su porvenir adverso e feliz. Sin una buena Constitución un pueblo siempre es retrógrado. No temamos las ideas avanzadas. Peores son las retrógradas. [...] Marchar adelante maldiciendo el pasado $^{28}$ y aspirando las brisas de la libertad, con elementos nuevos, con leyes liberales y con instituciones sabias, es nuestro deber como Paraguayos y la gloria mas imperecedera para nuestra querida Patria, digno en todo sentido de ser grande, feliz y prospera. Tal vez estemos equivocado, pero no transijiremos jamás con los que quieran desarraigar el pasado para envolvernos en las tinieblas, ú retrógrados teman las nuevas ideas por peligrosas. Lo que es bueno nunca es peligroso: son la ignorancia y las instituciones añejas las que deben temerse porque nada bueno pueden producir sino el despotismo y la corrupción. Temer la libertad es abrazar la esclavitud; solo los abyectos y serviles pueden proceder así. Ideas regeneradoras que han de dar el bautismo del porvenir a la juventud, principios eternos de verdad y justicia, inconmovibles á pesar del fanatismo y los retrógrados, práctica democrática y Gobierno de la libertad es lo único que nos conviene. (La Regeneración, Assunção, 21/11/1869)

A leitura deste texto permite perceber que os liberais debatiam com opositores que não acreditavam na efetividade de "ideias regeneradoras" ou de "princípios liberais" no Paraguai daquele contexto, os quais são denominados "retrógrados". A facção de Bareiro publicou o primeiro número de La Voz del Pueblo em 24 de março de 1870, tendo o seu "Programa" reproduzido pelo jornal La Tribuna de Buenos Aires:

\begin{abstract}
Aceptado por el Exmo. Gobierno Provisorio - y que la Voz del Pueblo levanta como bandera de su propaganda. Respetar fielmente los propósitos de la alianza manifestados en sus tratados públicos. Unión y fraternidad entre nacionales ${ }^{29} \mathrm{y}$ estrangeros, entre ambos y el Gobierno. Hacer que el Paraguay sea para todos, y que leyes liberales y protectoras sean el amparo de todo aquel que busca en el país por medio de su honrado trabajo la adquisición de una posición. Dejar que las ideas se manifiesten con libertad siempre que su propaganda no sea desquicio. Olvidar lo pasado $^{30}$; y con empeño y fé, buscar en el porvenir la reconstrucción del país. Ser el eco de los intereses comerciales por ser el comercio la vida de las naciones. En fin, levantar bien alto la bandera de la nacionalidad paraguaya, para que á su sombra se elabore el engrandecimiento del país. (La Tribuna, Buenos Aires, 01/04/1870)
\end{abstract}

Este Programa de La Voz del Pueblo evidencia, primeiramente, a condição necessária para a fundação de um jornal naquele contexto: ser aceito pelo Governo Provisório e pelas

\footnotetext{
${ }^{27}$ Grifos do autor.

${ }^{28}$ Grifos do autor.

${ }^{29}$ Grifos do autor.

${ }^{30}$ Grifos do autor.
}

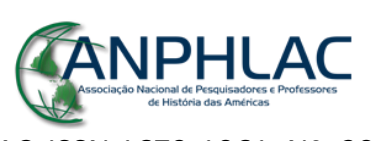


autoridades aliadas no Paraguai. Além disso, percebe-se que o liberalismo estava em disputa, pois era reclamado pelas duas facções, o que não era exclusividade dos grupos políticos paraguaios. Wasserman (2013, p. 14) assinala que, dada a base comum liberal, republicana e antirosista das facções políticas portenhas pós-Caseros, estas se distinguiam entre os que assumiam posições mais radicais e aqueles que adotavam posturas moderadas ou conservadoras. Álvaro Klafke, por sua vez, ao analisar a imprensa imperial na Guerra dos Farrapos no Rio Grande do Sul (1835-1845), ressalta que o liberalismo, enquanto conceito usado como arma na luta ideológica, estava em disputa entre legalistas e farroupilhas (KLAFKE, 2014).

Ambos os grupos se diziam liberais, contudo, Warren (2009, p. 72) assinala que a facção de Bareiro possuía uma feição mais conservadora, pois "creía que la política era la arte de lo militarmente posible". Whigham (2012, p. 404) endossa esta interpretação ao afirmar que "el Club del Pueblo profesaba la orientación más "liberal" entre las incipientes organizaciones políticas paraguayas", embora fossem muito idênticas em estrutura, estilo retórico e cultura política. Tomás Sansón Corbo (2012, p. 121) acrescenta, por sua vez, que o projeto de matriz liberal se impôs no Paraguai por meio da ação das forças de ocupação que condicionaram a gestão dos sucessivos governos e também mediante a imprensa e a educação. Cabe questionar, portanto, se haveria possibilidade de alguma liderança paraguaia manifestar-se antiliberal ou conservadora, tendo em vista que naquele contexto tal posição seria imediatamente tachada de lopista e acarretaria grande repúdio público, podendo até mesmo gerar agressões físicas e perseguições.

Apesar de mostrar que a facção bareirista também era influenciada pelo liberalismo, o Programa acima citado evidencia os pontos de discórdia com a facção liberal: o esquecimento do passado e a união de todos os paraguaios.

Ao referir-se ao passado paraguaio, os liberais o definiam como um período de trevas e de barbárie que deveria ser rechaçado, tal como aparece no anteriormente citado Proyecto de Juan José Decoud: "debemos arrancar de raíces todos los restos del pasado despotismo" e "Marchar adelante maldiciendo el pasado" (La Regeneración, Assunção, 21/11/1869). Por sua vez, os bareiristas eram menos críticos em relação ao passado paraguaio, defendendo somente seu esquecimento, de modo a evitar que mágoas pretéritas interrompessem a árdua tarefa de

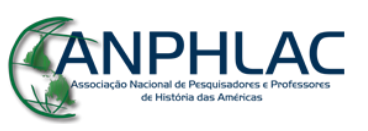


reconstrução nacional. Estes, membros do Club Unión que alterou o nome para Club del Pueblo, entendiam que a união e a fraternidade entre todos os paraguaios e estrangeiros eram fundamentais para superar a prostração em que se encontrava o país e proceder à sua reconstrução.

Os liberais, sobretudo a família Decoud, mostraram-se contrários às propostas de união entre todos os paraguaios e de esquecimento do passado. Em março de 1870, estabeleceu-se um debate público a respeito da união entre as duas facções, assunto do artigo "La unión de los clubs" publicado em La Regeneración:

\begin{abstract}
Se comprende que los hombres se unan para combatir a un enemigo común, o para llevar al primer puesto de la República a un ciudadano igualmente querido y popular. Pero no se comprende que los que ayer fueron verdugos y quieran aun serlo pretendan seducir y atraerse a sus víctimas; no se comprende cómo pueden abrazarse hombres que ayer servían al despotismo con atroz crueldad con hombres que han combatido constantemente ese despotismo, no como puede haber unión entre personas que no tienen más oficio que intrigar con los que proceden con altura y lealtad. ( $L a$ Regeneración, Assunção, 08/04/1870)
\end{abstract}

Para os liberais, a união entre as facções políticas poderia ocorrer desde que os indivíduos que haviam pertencido ou tido relação com os governos anteriores não participassem; em outras palavras, desde que Cándido Bareiro, líder da facção opositora e exrepresentante de Solano López na Europa, estivesse de fora, pois

\footnotetext{
¿Que és Bareiro bandera? holgazaneria, fiestas de cuarenta dias, y los vícios de prostitucion, borrachera \&. disimulo, delacion, jesuitismo, odio al estrangero, cadenas, azotes, traicion y asesinato del padre por el hijo, del hermano por el hermano, del amigo por el amigo, la degradacion moral intelectual y material; es decir la noche: Es decir el pasado. La noche es hija de la oscuridad infinita. Bareiro tiene partido: la noche. (El Paraguay, Assunção, 31/05/1870)
}

A respeito da dicotomia entre luz e trevas, à escuridão da noite haveria de opor-lhe a luz: "El Paraguay necesita algo más que una reforma: necesita los fuertes sacudimientos [ilegível] para despertar de ese largo y no interrumpido sueño que le infundiera el [ilegível] jenio jesuítico. Hoy pide a gritos y no se cansara de pedir - luz - luz" (La Regeneración, Assunção, 30/03/1870). Representar Cándido Bareiro e sua facção como a encarnação da

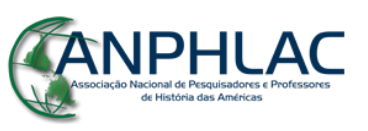


barbárie foi uma constante na imprensa liberal, pois, com isso, os liberais objetivavam desqualificar a imagem do líder do grupo opositor. Adolfo Decoud assim representava as facções políticas:

\begin{abstract}
Los partidos políticos que militan hoy en bandos opuestos, son también completamente opuestos en la idea que representan. Unos representan la reacción del pasado que está encarnado en los sicarios del tirano que pereció últimamente, que han esplotado la riqueza del Pueblo; otros representan la causa de las victimas, la causa de Yegros y Caballeros ${ }^{31}$ que sucumbieron antes que humillarse a los tiranos de su Patria. Unos representan lo que en la República Argentina se le dio nombre de Mazorca; otros lo que allí mismo se llamo unitários ${ }^{32}$. Unos están impulsados solamente por sus miras personales y por sus bolsillos; otros, el partido liberal, es el que quiere no a los Francia y Lopez, sino a ciudadanos íntegros y honrados, que se han sacrificado por su Patria. (La Regeneración. Assunção, $01 / 05 / 1870)$
\end{abstract}

Em outro momento, as críticas à facção e ao jornal de Bareiro se davam nos seguintes termos:

Los honrados laboriosos se desparraman por el suelo paraguayo a aplicar sus industrias, y los esplotadores ambiciosos se reconcentran en "La Voz del Pueblo", órgano que no representa ningún partido político, pero si la ambición de un hombre que pertenece a la época de la barbarie y desolación del Paraguay. [...] Decir á voces para que puedan creer los necios, que "La Voz del Pueblo" hace una propaganda liberal ${ }^{33}$; que se ocupa de los intereses vitales del país; que ilustra y enseña al pueblo en su marcha republicana; que predican la unión, la paz, la fraternidad a todos los paraguayos, y en seguida insitarlos a la revuelta, a la rebelión, aconsejándolos al desconocimiento de la autoridad nacional; no es a fé de caballero una acción infame digna solo de hombres sin dignidad ni honra? (El Paraguay, Assunção, 28/05/1870)

Frente a estas acusações, a facção de Bareiro acusava os liberais de formarem um reduzido círculo exclusivo de ilustrados que dividiam o povo paraguaio com o objetivo de atingir os seus próprios interesses pecuniários: "Los enemigos del pueblo están empeñados en hacer falsa propaganda. El circulo pequeño del Sr. De Rivarola, se va perdiendo cada dia..." (La Voz del Pueblo, Assunção, 19/07/1870). O partido de Bareiro também se apresentava como

\footnotetext{
${ }^{31}$ Fulgencio Yegros e Pedro Juan Caballero foram importantes personalidades políticas que planejaram uma conjura contra o ditador paraguaio Gaspar Rodrigues de Francia em 1820. Tendo sido descoberta previamente, inúmeros envolvidos foram condenados. Yegros foi fuzilado e Caballero teria se suicidado na prisão. (LOPEZ MOREIRA, 2013, p. 148)

${ }^{32}$ Grifos do original. Grupo político que defendia a criação de uma República Argentina unida e centralizada na capital Buenos Aires em oposição ao grupo que pregava a organização federal. (TERNAVASIO, 2013, p. 152)

${ }^{33}$ Grifos do autor.
}

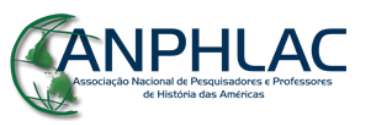

Revista Eletrônica da ANPHLAC, ISSN 1679-1061, №. 20, p. 222-255, Jan/Jun., 2016.

http://revista.anphlac.org.br 
o mais popular, sendo o nome do seu jornal La Voz del Pueblo, uma vez que este pueblo não teria voz no jornal opositor, que o queria regenerado:

\begin{abstract}
Nosotros no tomamos un puesto en las columnas de "La Voz del Pueblo" para atentar contra los intereses paraguayos, y prohijar los argentinos con mengua de los primeros; nosotros subimos a la prensa para ayudar con nuestro pobre contingente a centralizar, diré así, los diferentes grupos del pueblo paraguayo que vagaban a merced de un circulo exclusivo ${ }^{34}$; nosotros queremos ensanchar la acción de ese círculo y dar cabida a los repelidos. (La Voz del Pueblo, Assunção, 14/07/1870)
\end{abstract}

No número do mesmo dia, o colaborador anônimo Saicam defendia Cándido Bareiro da seguinte maneira:

\begin{abstract}
Bareiro para nosotros no representa un hombre, ostenta su prestijio la voluntad del pueblo paraguayo. ¿No merece ese puesto? $\mathrm{Si}$, lo merece; yo soy franco y no temo la censura por acre q' sea. En Bareiro he observado las cualidades que constituyen al buen gobernante; le he seguido con afán en todas sus fases como hombre público y he encontrado el hombre aparente para la situación. Prestijio entre nacionales y extranjeros, altura en las cuestiones, amante de su patria, pues desea verla independiente; firme en sus procederes, valor cívico; conocimientos en los negocios públicos, y amante del progreso. Esas son las cualidades mas resaltantes que forman el carácter de Bareiro, y es por eso que hemos acatado su candidatura que abiertamente la proclama el pueblo. [...] Otra pregunta, aunque más dura: cuál os conviene mas ¿Que predomine la influencia Brasilera en vuestra patria, ó la Argentina? ¿En donde encontrareis mas analogía de sistema político; mas afinidad, en el modo de ser de los pueblos? Responded jóvenes liberales. [...] Si mañana este pueblo se presenta con otro caudillo á su frente, q' corresponda a la libertad que se desea, yo lo victorearé; para mí el hombre es nada, la idea es todo. Bareiro representa la voluntad del pueblo paraguayo, y yo digo: viva el pueblo con su caudillo! Por eso siempre diré al pueblo ¡Adelante y viva la independencia! SAICAM. ( La Voz del Pueblo, Assunção, $14 / 07 / 1870)$
\end{abstract}

Como se percebe no texto, La Voz del Pueblo era um jornal de tendência pró-Argentina, sendo seu redator e alguns colaboradores daquela nacionalidade. Este fato não passou despercebido pelos liberais, que criticavam a condição de estrangeiros dos mesmos:

Nosotros, los humildes obreros del pensamiento, que nos honramos de pertenecer a esa ilustre pléyade de la juventud paraguaya símbolo del porvenir de la patria, solo hemos venido a la prensa a interpretar sus nobles aspiraciones, y a las del pueblo entero, en cuanto ellas sean compatibles con la independencia de nuestra ideas. Era necesario que el pueblo tuviese en la prensa dignos y lejitimos representantes salidos

${ }^{34}$ Grifos do autor.

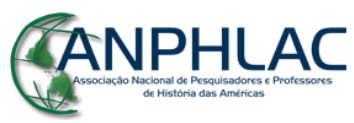

Revista Eletrônica da ANPHLAC, ISSN 1679-1061, №. 20, p. 222-255, Jan/Jun., 2016.

http://revista.anphlac.org.br 
de sus propias filas, y no a falsos profetas llegados á la ventura a nuestras playas ${ }^{35}$, ajenos a las desgracias de la patria. (La Opinión Pública, Assunção, 06/11/1870)

Outro tema de constante debate entre os jornais paraguaios era a posição frente ao Governo Provisório, sendo uma constante a acusação de oficialismo, de serem meros órgãos oficiais do Governo, entre as facções, uma vez que ambas foram, de algum modo, "oficialistas" durante aqueles meses iniciais de ocupação: a facção liberal até setembro de 1870 e a facção de Bareiro a partir de então. No artigo intitulado "El pueblo ve claro", o redator de $\mathrm{La} \mathrm{Voz} \mathrm{del}$ Pueblo orientava o triunviro Cirilo Rivarola a se desligar do Gran Club del Pueblo, pois os integrantes desta facção, mesmo sendo oficialistas, estariam a criticá-lo:

Los verdaderos enemigos del Sr. De Rivarola, están empeñados todos los días en hacerle flacos servicios, servicios que el pueblo juicioso los mira como flechas dirijidas al corazón con la idea de darle muerte instantánea. No permita el Sr. De Rivarola que lo pongan en ridículo cada día. Sacuda esa basura que se le pega al cuerpo, y gaste sus pesos en algo que le sea de más provecho. Los 1200 fuertes que le da a un diario para que lo ataque en lugar de defenderlo, repártalos entre los pobres en media plaza, que eso al fin le dará provechoso prestijio. [...] Los verdaderos enemigos del Gobierno son los que tratan de desprestijiarlo por todos los medios posibles, tanto en la prensa donde no lo defienden por no darle prestijio al Sr. De Rivarola... (La Voz del Pueblo, Assunção, 19/07/1870)

Se for verdadeiro o dado divulgado, 1200 pesos fortes seria a quantia paga pelo Governo Provisório ao oficialista La Regeneración pela publicação de documentos oficiais, o que lhe rendia a acusação de estar vendido ao Governo, como se percebe no texto a seguir:

Este Gobierno sin opinión, sin prestijio y sin ningún tino para ejercer el mandato que le confiaron los Aliados, y un reducidísimo número de paraguayos, tiene sin embargo que venir al suelo, el primer día que se instale la Convención, ÚNICA AUTORIDAD LEJÍTIMA, DE ORIGEN POPULAR. Para entonces los enemigos del partido nacional, que ahora quiere combatir el que se ha conchabado ayer en el extranjero, por un buen salario, para venir a escribir aquí, sobre sucesos que no conoce más que por el metálico que guarda cada mes, entonces decimos han de ver aquellos su error, y tal vez se acuerden que son [ilegível] y que deben concurrir unidos á la felicidad de su país. (La Voz del Pueblo, Assunção, 19/07/1991)

Neste texto, o redator de La Voz del Pueblo criticava os membros da facção liberal ao assinalar que estes constituíam um reduzido número de paraguaios reunidos no exterior para

${ }^{35}$ Grifos do autor.

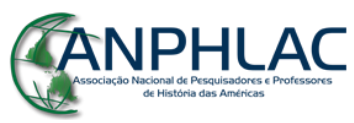

Revista Eletrônica da ANPHLAC, ISSN 1679-1061, №. 20, p. 222-255, Jan/Jun., 2016.

http://revista.anphlac.org.br 
retornar ao país, e que estavam interessados somente no dinheiro que lhes pagava o governo, resultando ser, deste modo, um grupo de oportunistas que ainda iriam reconhecer seu erro e concorrer à união de todos os paraguaios.

Na edição do dia 20 de março de 1870 de La Regeneración, José Segundo Decoud publicou um editorial, em primeira página e primeira coluna, intitulado "Declaración al pueblo", no qual rebatia as acusações de oficialismo com os seguintes termos:

Tanto la prensa estrangera como las correspondencias particulares se han ocupado con frecuencia de "La Regeneración" llamándola diario oficial, y calificando sus noticias y artículos de oficiales también, por más que en ellos, se patentice la independencia y la imparcialidad del autor. [...]

En vista de esto declaramos formalmente que "La Regeneración” no es un periódico oficial ni en su redacción ni en sus noticias, que el Gobierno no es sino un simple suscritor con quien se ha contratado publicar sus documentos y hacerle toda clase de obras, y que, sus dueños están resueltos a no ser jamás ecos de un gabinete ó de un gobierno, sino la voz, los ecos y la palabra del pueblo. (La Regeneración, Assunção, 20/03/1870)

Com o episódio de $1^{\circ}$ de setembro, o Gran Club del Pueblo passou a ser oposição ao governo e logo sentiu as consequências: ainda naquele mês, La Regeneración deixava de circular devido à destruição de sua impressora, e, em novembro, La Opinión Pública era interditada por ordens do governo. Neste último, Pedro Vera e José Segundo Decoud criticavam Rivarola e denunciavam o oficialismo de La Voz del Pueblo nos seguintes termos:

El colega dice: que Rivarola tiene a su favor la opinión pública nacional, el consentimiento unánime del Pueblo paraguayo, además de ser el único digno de ocupar el primer puesto. Esto es completamente falso... [...] Dice también el colega que de la elevación del Sr. Rivarola al primer puesto, resulta la unión de los paraguayos, porque Rivarola representa la cabeza de un partido. También en esta parte falta el colega a la verdad; porque mal puede hablar de unión de partidos, desde que el Sr. Rivarola dejó de ser cabeza del partido liberal, cuando traicionó el primero de Setiembre desde aquella fecha el Sr. Rivarola no es sino un traidor apóstata de aquel partido. Añade el colega que el Rivarola de antes hoy es el Rivarola del pueblo. Esto tampoco es cierto; porque Rivarola nunca ha sido, ni será del Pueblo. [...] Luego, si todo lo que dice el colega es falso como le hemos probado hasta la evidencia: el colega es un mentiroso, el colega miente y por fin el colega habla por seguir únicamente el compas al sonido sonoro que hace las libras al caer en la bolsa de subvención ${ }^{36}$. (La Opinión Pública, Assunção, 13/11/1870)

${ }^{36}$ Grifos do autor.

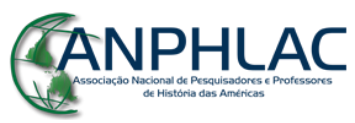

Revista Eletrônica da ANPHLAC, ISSN 1679-1061, №. 20, p. 222-255, Jan/Jun., 2016.

http://revista.anphlac.org.br 
Ao acusar La Voz del Pueblo de oficialista e vendido ao governo, os responsáveis por La Opinión Pública ressaltavam ser este jornal independente e porta-voz da opinião dos paraguaios: "El periódico que dirijimos es redactado por todo el pueblo: es su más perfecta espresion; por que como órgano independiente, sostenido [ílegible] pecuniarios, solo aspira al bien común de todos los paraguayos, a la felicidad de la Patria." (La Opinión Pública, Assunção, 16/11/1870). Percebe-se, portanto, que as acusações de oficialismo e oportunismo fizeram parte das acusações de ambas as facções quando estas foram oposição ao Governo Provisório.

Liberais e bareiristas, através dos seus órgãos difusores, não pouparam críticas uns em relação aos outros. A luta pelo poder entre as duas agrupações políticas assumiu um caráter faccionalista que em alguns momentos levou a enfrentamentos nas ruas de Assunção. Para Juan Crichigno (2010, p. 27), a rivalidade entre os grupos adquiriu características sórdidas, violentas e trágicas ao longo da década de 1870 . Harris Warren, por sua vez, destaca que a liberdade de imprensa foi um ideal não realizado durante os governos paraguaios pós-Cerro Corá e conclui: "La falta de tolerancia con la crítica periodística fue actitud prevaleciente de casi toda la historia paraguaya, con algunas excepciones a fines del siglo XIX” (WARREN, 2009, p. 240).

A falta de tolerância, em conjunto com a situação de anarquia política, econômica e social em um contexto de ocupação militar geraram condições extremamente instáveis e precárias para a atuação jornalística. Além de representar as agrupações políticas a que pertenciam, de promover debates a respeito de importantes temas para a sociedade paraguaia e de estarem constantemente buscando novos ingressos que permitissem a continuidade dos seus empreendimentos jornalísticos, os redatores, editores, proprietários e colaboradores dos jornais consultados também tiveram que lidar com as pressões, as prováveis ameaças de ataques e agressões e com os distúrbios, os quais, como se mostrou anteriormente, chegaram inclusive a ocasionar vítimas fatais.

\section{Considerações finais}


Inúmeros foram os temas de debate público que mobilizaram as duas facções políticas surgidas no imediato pós-guerra, debates estes que versaram principalmente a respeito do passado e das medidas a serem implementadas para a reconstrução/regeneração do Paraguai. Enquanto os liberais pregavam a regeneração por meio da educação, da imigração norteeuropeia e da instituição de uma constituição liberal, a facção de Cándido Bareiro adotou um liberalismo de caráter pragmático que defendia a união entre todos os paraguaios e o esquecimento do passado como condições necessárias para a reconstrução do país, procurando apresentar-se como mais popular do que a facção opositora.

Embora ambos os grupos compartilhassem, ou pelo menos aparentassem partilhar, uma base liberal, republicana e antilopista, as disputas personalistas e as acusações de oficialismo foram uma constante nos meses de ocupação aliada de Assunção, cidade na qual passaram a circular os primeiros jornais independentes da história paraguaia. Enquanto a facção liberal contava com La Regeneración, El Paraguay e La Opinión Pública, a facção de Cándido Bareiro tinha La Voz del Pueblo como seu órgão representante, os quais inauguraram a prática de debates públicos e livres no país. Embora tenham circulado por um curto período, estes jornais assumiram um importante papel no cenário político paraguaio, pois levaram temas de considerável relevância para o debate público e influenciaram as disputas políticas durante os meses em que se discutia o caráter da Constituição que iria reger o país a partir de 1870, algo inédito até o episódio de Cerro Corá.

\section{Fontes consultadas}

El Nacional - Hemeroteca da Biblioteca do Congresso Nacional da República Argentina.

El Paraguay - Biblioteca Nacional do Paraguai.

El Siglo - Biblioteca Nacional do Uruguai.

La Nación - Hemeroteca da Biblioteca do Congresso Nacional da República Argentina.

La Opinión Pública - Biblioteca Nacional do Paraguai.

La Tribuna - Hemeroteca da Biblioteca do Congresso Nacional da República Argentina.

La Voz del Pueblo - Instituto Histórico-Geográfico do Rio Grande do Sul (IHGRS).

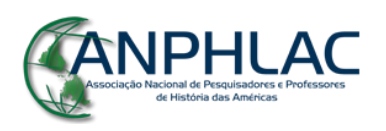

Revista Eletrônica da ANPHLAC, ISSN 1679-1061, №. 20, p. 222-255, Jan/Jun., 2016.

http://revista.anphlac.org.br 
La Regeneración - Biblioteca Nacional do Paraguai.

\section{Referências bibliográficas}

ACOSTA TOLEDO, Gustavo Alfredo. Posguerra contra la Triple Alianza: Aspectos Políticos e Institucionales (1870-1904). Asunción: Servilibro, 2013.

ALONSO, Paula. Introducción. In: ALONSO, Paula (Org.). Construcciones Impresas: Panfletos, diarios y revistas en la formación de los Estados nacionales en América Latina, 18201920. Buenos Aires: FCE, 2004, p. 7-12.

AMIGO, Roberto. La alegoría republicana en las trincheras, una introducción a Cabichuí. In: ESCOBAR, Ticio; SALERNO, Osvaldo (Comp.). Cabichuí. Periódico de la Guerra de la Triple Alianza. Asunción: Servilibro/Museo del Barro, 2016.

ACREE, William. La lectura cotidiana: Cultura impresa e identidad colectiva en el Río de la Plata, 1780-1910. Buenos Aires: Prometeo Libros, 2013.

ARECES, Nidia. De la Independencia a la Guerra de la Triple Alianza (1811-1870). In: TELESCA, Ignacio (Org.). Historia del Paraguay. Asunción: Prisa Ediciones, 2011, p. 149197 .

BARBOSA, Marialva. História cultural da imprensa: Brasil, 1800-1900. Rio de Janeiro: Mauad X, 2010.

BARATTA, María Victoria. ¿Aliados o enemigos? Las representaciones de Brasil en el debate público argentino durante la Guerra del Paraguay (1864-1870). Revista de História, São Paulo, n. 172, p. 1-34, jan./jun. 2015.

BERNALDO, Pilar González. Espacios y formas de sociabilidad. In: TERNAVASIO, Marcela (Org.). Historia de la provincia de Buenos Aires: de la organización provincial a la federalización de Buenos Aires: 1821-1880. Buenos Aires: EDHASA; UNIPE; Editorial Universitaria, 2013, p. 349-373.

BREZZO, Liliana. La Argentina y el Paraguay, de la guerra a la integración. Imagen histórica y relaciones internacionales. Rosario: Instituto de Historia/Facultad de Derecho y Ciencias Sociales de Rosario/PUCA, 1999.

. Reconstrucción, poder político y revoluciones (1870-1920). In: TELESCA, Ignacio

(Org.). Historia del Paraguay. Asunción: Prisa Ediciones, 2011, p. 199-224.

CAMPOS, Herib Caballero; SEGOVIA, Cayetano F. El Periodismo de Guerra en el Paraguay (1864-1870). In: Nuevo Mundo Mundos Nuevos. [en línea] Coloquios. Puesto en línea el $1^{\circ} \mathrm{de}$

\section{GANPHLAC}


febrero de 2006. Acesso em 23 de Abril de 2016. http://nuevomundo.revues.org/1384; DOI: 10:4000.

CAPELATO, Maria Helena Rolim. A imprensa na história do Brasil. São Paulo: Contexto/EDUSP, 1988.

CRICHIGNO, Juan. Diarios del Paraguay. Asunción: ABC, Centro Gráfico, 2010.

DARNTON, Robert. O beijo de Lamourette. Mídia, Cultura e Revolução. São Paulo: Companhia das Letras, 1990.

DE LUCA, Tânia Regina. História dos, nos e por meio dos periódicos. In: Fontes Históricas. São Paulo: Contexto, 2005.

DE MARCO, Miguel Angel. Historia del Periodismo Argentino: desde los orígenes hasta el Centenario de Mayo. Buenos Aires: Educa, 2006.

DI MEGLIO, Gabriel. ;Mueran los salvajes unitarios! La Mazorca y la política en tiempos de Rosas. Buenos Aires: Sudamericana, 2007.

DORATIOTO, Francisco Monteoliva. A ocupação político-militar brasileira do Paraguai (1869-76). In: CASTRO, Celso; IZECKSOHN, Vitor; KRAAY, Hendrik (Orgs.). Nova História Militar Brasileira. Rio de Janeiro: Editora FGV, 2004, p. 209-235.

. De aliados a rivais: o fracasso da primeira cooperação entre Brasil e Argentina (18651876). Revista Múltipla, Brasília, v. 4, p. 21-40, 1999.

Letras, 2002.

Maldita Guerra: Nova história da Guerra do Paraguai. São Paulo: Companhia das O Brasil no Rio da Prata (1822-1994). Brasília: FUNAG, 2014.

ESCOBAR, Ticio. A gravura popular, outra imagem da guerra. In: Maria M. Marques (Org.). A guerra do Paraguai: 130 anos depois. Rio de Janeiro: Relume-Dumará, 1995, p. 121-129.

El arte de la guerra. Los grabados del periodismo durante la Guerra Guasu. In: ESCOBAR, Ticio; SALERNO, Osvaldo (Comp.). Cabichuí. Periódico de la Guerra de la Triple Alianza. Asunción: Servilibro/Museo del Barro, 2016.

ESTEVES, Gomes. Historia Contemporánea del Paraguay. Asunción: El Lector, 1996.

HABERMAS, Jurgen. Mudança estrutural da esfera pública: investigações sobre uma categoria da sociedade burguesa. São Paulo: Editora Unesp, 2014.

\section{CANPHLAC}

Revista Eletrônica da ANPHLAC, ISSN 1679-1061, №. 20, p. 222-255, Jan/Jun., 2016.

http://revista.anphlac.org.br 
HAVELOCK, Eric. A equação oralidade-cultura escrita: uma fórmula para a mente moderna. In: OLSON, David; TORRANCE, Nancy (Org.). Cultura escrita e oralidade. São Paulo: Ática, 1995.

HORA, Roy. Historia económica de la Argentina en el siglo XIX. Buenos Aires: Siglo Veintiuno Editores, 2010.

JOHANSSON, María Lucrecia. Paraguay contra el monstruo antirrepublicano. El discurso periodístico paraguayo durante la Guerra de la Triple Alianza (1864-1870). Revista Historia Critica, Bogotá, n. 47, p. 71-92, mayo-agosto, 2012.

KLAFKE, Álvaro. A imprensa legalista na Guerra dos Farrapos. In: NEUMANN, Eduardo; GRIJÓ, Luiz Alberto (Orgs.). O Império e a Fronteira. A Província de São Pedro nos oitocentos. São Leopoldo: Oikos, 2014.

LÓPEZ MOREIRA, Mary Monte. Historia del Paraguay. Asunción: Servilibro, 2013.

MOREL, Marco. Para além das letras. Apontamentos sobre imprensa e oralidade na primeira metade do século XIX. Revista Acervo, Rio de Janeiro, v. 23, n.1, p. 63-80, jan./jul., 2010.

ORTOLAN, Fernando. Dócil, elegante e caridosa: representações das mulheres paraguaias na imprensa do pós-Guerra do Paraguai (1869-1904). Curitiba, 2010. Tese de Doutorado, UFPR.

PUSINERI, Adelina. Las luchas político-democráticas a través de la prensa y la Convención Nacional Constituyente de 1870. Diálogos, Maringá, v. 9, n. 2, 2005, p. 37-65.

RÉMOND, René (Org.). Por uma história política. Rio de Janeiro: FGV, 2003.

ROLÓN, Oscar Bogado. Sobre Cenizas: Construcción de la Segunda República del Paraguay - 1869/1870. Asunción: Editora Intercontinental, 2011.

SABATO, Hilda. Historia de la Argentina, 1852-1890. Buenos Aires: Siglo Veintiuno, 2012.

La política en las calles: Entre el voto y la movilización. Buenos Aires, 1862-1880. Bernal: Universidad Nacional de Quilmes, 2004.

La vida pública en Buenos Aires. In: BONAUDO, Marta (Org.). Liberalismo, estado y orden burgués. Nueva Historia Argentina, T. 4. Buenos Aires: Sudamericana, 2007, p. 161216.

SANSÓN CORBO, Tomás. Sociedad, estado e identidad en el Paraguay posbélico en la visión de José Segundo Decoud. Revista Paraguaya de Sociología, Asunción, ano 49, n. 141, 2012.

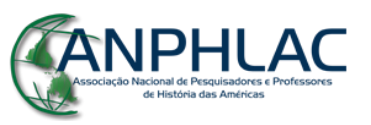

Revista Eletrônica da ANPHLAC, ISSN 1679-1061, №. 20, p. 222-255, Jan/Jun., 2016.

http://revista.anphlac.org.br 
SEIFERHELD, Alfredo. El Cabichuí en el contexto histórico de la Guerra Grande. In: ESCOBAR, Ticio; SALERNO, Osvaldo (Comp.). Cabichuí. Periódico de la Guerra de la Triple Alianza. Asunción: Servilibro/Museo del Barro, 2016.

SILVA, Alberto M. R. A noite das Kygua Vera: a mulher e a reconstrução da identidade nacional paraguaia após a Guerra da Tríplice Aliança (1867-1904). Tese, UFF, 1998.

TERNAVASIO, Marcela. Historia de la Argentina, 1806-1852. Buenos Aires: Siglo Veintiuno Editores, 2013.

TORAL, André. Imagens em desordem, a iconografía da Guerra do Paraguai (1864-1870). São Paulo: Humanitas, FFLCH/USP, 2001.

ZALAZAR, Raquel. Regeneración de la sociedad paraguaya: aporte de los inmigrantes (18701904). Diálogos, Maringá, v. 9, n. 2, 2005, p. 67-78.

WARREN, Harris Gaylord. Paraguay y la Triple Alianza: La Década de Posguerra: 1869-1878. Asunción: Intercontinental, 2009.

WASSERMAN, Fabio. La libertad de imprenta y sus límites: prensa y poder político en el Estado de Buenos Aires durante la década de 1850. Revista Almanack Braziliense, São Paulo, n. 10, nov. 2009, p. 130-146.

La política, entre el orden local y la organización nacional. In: TERNAVASIO, Marcela (Org.). Historia de la provincia de Buenos Aires: de la organización provincial a la federalización de Buenos Aires: 1821-1880. Buenos Aires: EDHASA; UNIPE; Editorial Universitaria, 2013, p. 153-178.

WHIGHAM, Thomas. La Guerra de la Triple Alianza. Danza de muerte y destrucción. Asunción: Taurus, 2012. Volumen III. 